\title{
PASHA: A NEW INDUSTRIAL PROCESS TECHNOLOGY ENABLING HIGH EFFICIENCIES ON THIN AND LARGE MC-SI WAFERS
}

\author{
Ingrid Romijn, Ilkay Cesar, Martien Koppes, Eric Kossen and Arthur Weeber \\ ECN Solar Energy, P.O. Box 1, 1755 ZG Petten, The Netherlands \\ Tel: +31 22456 4309, Fax: +31 22456 8241, Email: Romijn@ecn.nl
}

\begin{abstract}
To maintain high efficiencies for solar cells and reduce the cell bowing, the full Al rear surface of thin conventional solar cells has to be replaced by a more suitable passivating rear surface layer. In our new PASHA-cell (Passivated on All Sides $\underline{H}$-patterned cell) we apply a single silicon-nitride $\left(\mathrm{SiN}_{\mathrm{x}}: \mathrm{H}\right)$ layer for rear surface passivation in combination with an open, firing through aluminum metallization. This improved processing results in a gain in efficiency of almost $1 \%$ absolute compared to full Al BSF, achieving $16.4 \%$ on $156 \mathrm{~cm}^{2}, 200 \mu \mathrm{m}$ thick $\mathrm{mc}$ Si solar cells. Besides this efficiency gain, due to lower consumption of aluminum, there will be a reduction in the costs of cell fabrication. Furthermore, the severe bowing of wafers thinner than $200 \mu \mathrm{m}$ has been reduced to zero.

To test the industrial stability, the processing was applied on a batch of large $\left(243 \mathrm{~cm}^{2}\right)$ and thin (160 $\mu \mathrm{m})$ wafers which yielded an average cell efficiency of $15.5 \%$ with a maximum of $16.1 \%$. This is $0.5 \%$ absolute better than the full Al rear reference, even though the rear metallization pattern has not been optimized yet.
\end{abstract}

\section{INTRODUCTION}

A general trend to reduce costs for $\mathrm{PV}$ is to reach high efficiencies on thin and large solar cells. However, processing of thin $(<200 \mu \mathrm{m})$ and fragile wafers using today's technology with full rear surface aluminum Back Surface Fields (BSF) will reduce the cell efficiency due to non-optimal back-surface passivation and lower internal reflection at the rear side [1-7]. Furthermore, the use of such wafers will cause problems for processing and module assembly due to the increased bowing which will result more breakage. In the past couple of years several solutions to overcome these bottlenecks have put forward: the usage of bifacial rear side passivated solar cells $[1,2]$, passivating the rear side with dielectric layers and using laser fired contacts (LFC) at the rear $[3,4]$, or selective alloying of a local BSF at the rear (i-PERC) $[5,6]$. While in the case of bifacial cells only part of the rear surface is covered with metallization, in the case of the LFCs or i-PERC a full Al layer is deposited on top of the passivating layer(s). This full Al layer can result in higher fill factor (FF) of the solar cells due to reduction in $\mathrm{R}_{\text {series, }}$, but removes the possibility of bifacial use and of further cost reduction by lower aluminum consumption.

To increase the efficiency for thin cells, a single $\mathrm{SiN}_{\mathrm{x}}$ passivating layer is used at the rear. Open rear metallization of the bifacial cells reduces the cell bowing to zero $[1,2]$. The FF of the PASHA (Passivated on All Sides $\underline{H}$-patterned cells) cells will be improved by optimizing the metallization pattern.

\section{EXPERIMENTS AND PROCESSING}

\section{Processing of the PASHA cells}

The processing sequence of the PASHA cells, as it is carried out in the ECN laboratory, is shown in figure 1. P-type mc-Si wafers are iso-textured by a wet chemical acidic etch, after which a $65 \Omega / s q$ emitter is diffused using an inline belt furnace. To prepare the rear surface for optimal passivation, the rear side emitter is removed using a wet chemical etch after which the rear surface is smoothened for better passivation. Before $\mathrm{SiN}_{\mathrm{x}}$ deposition the P-glass is removed and the wafers are cleaned. The standard ECN remote MW PECVD SiN $_{x}$ coating [8] is used as a front side anti-reflection layer and for bulk and surface passivation [9]. On the rear side a single $\mathrm{SiN}_{\mathrm{x}}$ layer is applied, using the same remote MW PECVD system. The metallization is applied by screen printing, silver on the front side and an H-pattern aluminum metallization for rear side contacting and local BSF formation. The aluminum paste used was specially developed to enable firing through the $\operatorname{SiN}_{x}$ on the rear side. Both the silver front and aluminum rear contacts were fired through the $\mathrm{SiN}_{\mathrm{x}}$ layers in a single co-firing step. Because the emitter on the rear surface is removed in step 3 (fig 1), no edge isolation (e.g. laser) is needed. Thus, effectively only one additional process step, the additional $\mathrm{SiN}_{\mathrm{x}}$ layer at the rear, is needed with respect to the conventional mc-Si processing. This means that the process can be easily implemented into industry.

Cell processing

\begin{tabular}{|c|}
\hline Isotexture \\
\hline Emitter diffusion \\
\hline Rear emitter removal, smoothing \\
\hline P-glass removal, clean \\
\hline Fear side passivating layer \\
\hline Ag front metallization \\
\hline Cl and Ag rear metallization \\
\hline Co-firing \\
\hline IV, spectral response, reflection, \\
IQE
\end{tabular}

Figure 1: Flow chart of processing of and experiments on PASHA cells

\section{Optimization of the rear side passivation}

For the passivation of the rear surface of $p$-type solar cells (lowly doped p-type silicon), several institutes have developed different layered structures. Both the $\mathrm{SiO}_{\mathrm{x}} / \mathrm{SiN}_{\mathrm{x}}$ and $\mathrm{SiO}_{\mathrm{x}} / \mathrm{SiN}_{\mathrm{x}} / \mathrm{SiO}_{\mathrm{x}}$ stacked layers used by IMEC and ISE [4-6], and the a-Si layer used by ISE in the LFC solar cells [3] give excellent rear surface passivation. Our aim was to develop a single passivating layer that can be easily applied in 
industry. Therefore, we investigated single layers of hydrogenated silicon nitride $\left(\mathrm{SiN}_{\mathrm{x}}\right)$, since they are already very common in use for the front surface and bulk passivation of most industrial Si solar cells.

In figure 2 we show the surface recombination velocities of the different $\mathrm{SiN}_{\mathrm{x}}$ layers as a function of their Si-N bond density, before and after firing [9]. All layers were deposited on $1 \mathrm{ohm}-\mathrm{cm}$, double polished p-type FZ wafers. The effective lifetimes $\left(\tau_{\text {eff }}\right)$ of the samples were measured using Quasi Steady State Photo Conductance method [10]. Recombination velocities $\left(S_{\text {eff }}\right)$ were calculated using the approximation: $1 / \tau_{\text {eff }}=1 / \tau_{\text {bulk }}+2 S_{\text {eff }} / \mathrm{W}$, with $\mathrm{W}$ the thickness of the $F Z$ wafer [11]. $\tau_{\text {bulk }}$ is assumed to be $1 \mathrm{~ms}$ for the FZ material. As can be seen from figure 2 , our $\mathrm{SiN}_{\mathrm{x}}$ layers are able to give an excellent passivation, with $S_{\text {eff }}$ ranging from 100 to $10 \mathrm{~cm} / \mathrm{s}$, on lowly doped p-type surfaces.

Using standard remote MW PECVD $\operatorname{SiN}_{x}$ deposition, we found an optimum in surface passivation for layers with Si-N $\sim 9.5^{*} 10^{23} \mathrm{~cm}^{-3}$, and refractive index of $n \sim 2.5$. With further optimizing we were able to reduce the recombination velocity to values below $10 \mathrm{~cm} / \mathrm{s}$. These layers were used on the rear side of the PASHA cells.

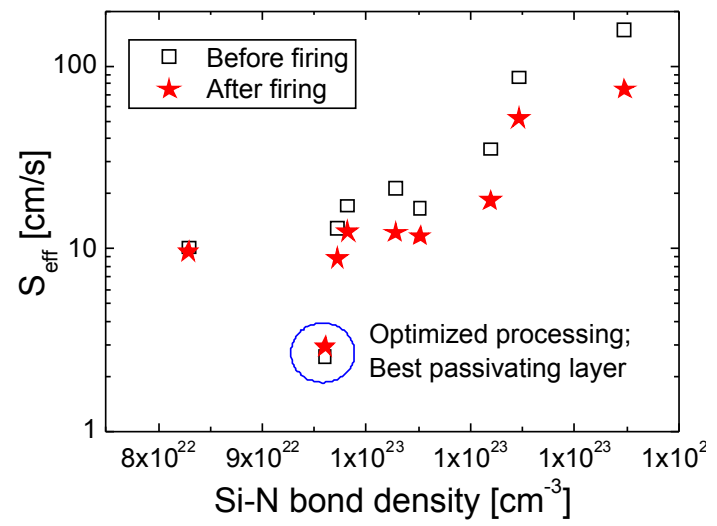

Figure 2: Recombination velocities of different silicon nitride coatings as a function of their Si-N bond density, before and after firing.

\section{Results of PASHA cells}

Pasha cells were processed in the lab on $240 \mu \mathrm{m}$ thick, $156 \mathrm{~cm}^{2} \mathrm{mc} \mathrm{Si}$ material using different $\mathrm{SiN}_{\mathrm{x}}$ coatings on the rear side. The values for implied $V_{o c}$ at 1 sun illumination were extracted from the injection dependent lifetime measurements [10]. Implied $V_{o c}$ 's of over $660 \mathrm{mV}$ were achieved after firing for wafers passivated with the best rear surface layer.

IV characteristics of the complete solar cells were measured using a Class A solar simulator according to the ASTM-E948 norm, full area Internal Quantum Efficiency (IQE) was calculated from spectral response and reflection measurements. The averaged results for $J_{s c}$ and $V_{o c}$ for PASHA cells with two different rear surface passivating layers, a full aluminum reference cell and a cell with no passivating layer are shown in figure 3 and table 1. The final values for $V_{o c}$ after complete processing are about $40 \mathrm{mV}$ lower than the implied $\mathrm{V}_{\mathrm{oc}}$ measured. This is due to the additional handling, metallization steps and the firing of the aluminum pattern through the rear side passivating coating. The current obtained with the best surface passivating $\mathrm{SiN}_{\mathrm{x}}(35$ $\mathrm{mA} / \mathrm{cm}^{2}$, see table I) is $\sim 3 \%$ higher than the $J_{\mathrm{sc}}$ of the Al reference $\left(33.9 \mathrm{~mA} / \mathrm{cm}^{2}\right)$, the $\mathrm{V}_{\text {oc }}(609 \mathrm{mV})$ is slightly higher to the reference value of $607 \mathrm{mV}$. This indicates that $\mathrm{J}_{\mathrm{sc}}$ is most susceptible to fine-tuning of rear surface optimization.

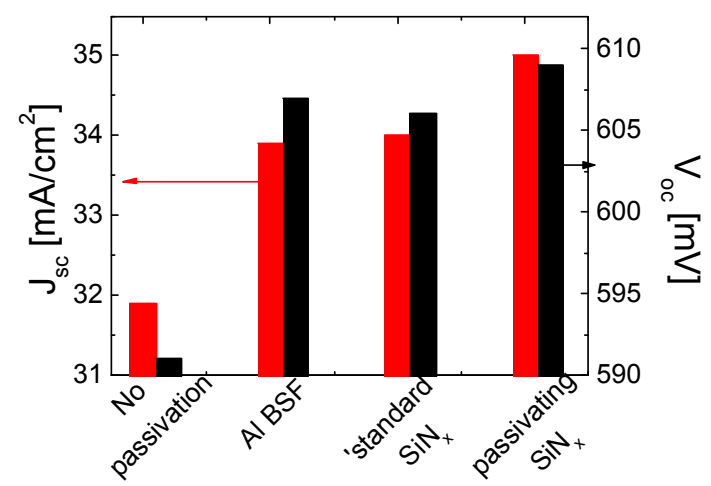

Figure 3: Average IV results (red $\mathrm{J}_{\mathrm{sc}}$, black $\mathrm{V}_{\mathrm{oc}}$ ) for mc-Si solar cells with different rear surface passivation

Table I: average IV results of $\mathrm{mc}-\mathrm{Si}$ bifacial solar cells, and a full Al reference cell

\begin{tabular}{|c|c|c|c|c|}
\hline Rear Side & $\begin{array}{l}\mathrm{J}_{\mathrm{Sc}} \\
\left(\mathrm{mA} / \mathrm{cm}^{2}\right)\end{array}$ & $\begin{array}{l}V_{O C} \\
(m V)\end{array}$ & $\begin{array}{l}\mathrm{FF} \\
(\%)\end{array}$ & $\begin{array}{l}\eta \\
(\%)\end{array}$ \\
\hline $\begin{array}{l}\text { No } \\
\text { passivatin } \\
\text { g layer }\end{array}$ & 31.9 & 591 & & \\
\hline $\begin{array}{ll}\text { Full } & \mathrm{Al} \\
\text { rear } & \\
\end{array}$ & 33.9 & 607 & 75.6 & $\begin{array}{l}15 . \\
5 \\
\end{array}$ \\
\hline $\begin{array}{l}\text { standard } \\
\operatorname{SiN}_{x} \text { rear }\end{array}$ & 34.0 & 606 & 73.2 & $\begin{array}{l}15 . \\
1\end{array}$ \\
\hline $\begin{array}{l}\text { surface } \\
\text { passivatin }\end{array}$ & $\begin{array}{l}35.0 \\
(\max \end{array}$ & $\begin{array}{l}609 \\
(\max \end{array}$ & 77 & $\begin{array}{l}16 . \\
4\end{array}$ \\
\hline$\underset{\text { rear }}{\text { g }} \quad \operatorname{SiN}_{x}$ & $35.2)$ & 611) & & \\
\hline
\end{tabular}

\section{Analysis and discussion of PASHA cells}

The internal quantum efficiency measurements from the rear side of the solar cells with different rear side passivation schemes are shown in figure 4 , including the fits from the PC-1D analysis.

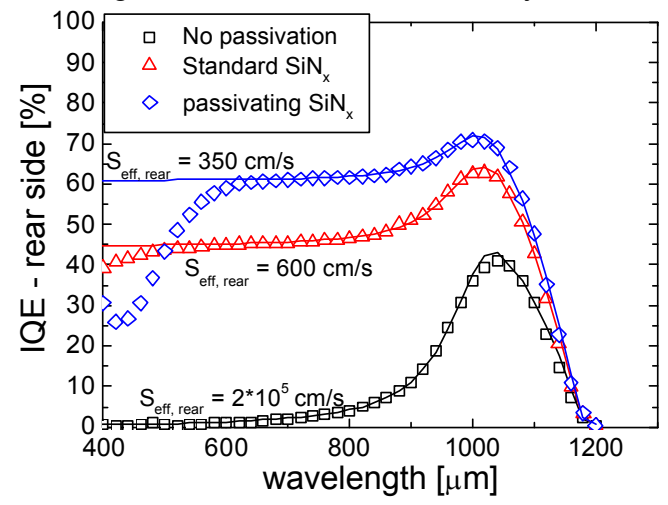

Figure 4: Rear side illuminated IQE measurements and PC1D fits. For the lower wavelengths $(<500 \mathrm{~nm})$ the results are affected by the absorption in the passivating layers. This causes a lower IQE, which 
could not be fitted with PC1D. When the cell is illuminated from the front, this absorption at lower wavelengths at the rear will not hinder the cell efficiency.

Since all the cells were made of neighboring material and, except for the backside passivation, were identically processed, values for $\tau_{\text {bulk }}$ are similar (around 25-30 $\mu \mathrm{s}$ ) and the front parameters such as front surface passivation $\left(2.5^{*} 10^{5} \mathrm{~cm} / \mathrm{s}\right)$ and internal, front side reflection (85\%) were the same for all groups. A lowest value of $S_{\text {eff,rear }}=350 \mathrm{~cm} / \mathrm{s}$ is obtained for the cells passivated with the 'optimized' single $\mathrm{SiN}_{\mathrm{x}}$ layer.

In figure 5, both the front- and rear-IQE of a rearpassivated $\mathrm{mc}-\mathrm{Si}$ cell (using best passivating $\mathrm{SiN}_{\mathrm{x}}$ ) are shown together with the front-IQE of the full aluminum reference cell. At $1000 \mathrm{~nm}$, the two frontIQEs are overlapping. This means that the full aluminum rear solar cell has similar low rear surface recombination velocities (fitted with PC1D [12] to $S_{\text {eff rear }} \sim 350 \mathrm{~cm} / \mathrm{s}$ ) as the rear side passivated solar cell [8]. Such low recombination values for BSFs are not usually obtained in industry, where the values for $S_{\text {eff,rear }}$ are usually above $1000 \mathrm{~cm} / \mathrm{s}$ [7]. Above 1000 $\mathrm{nm}$ however, there is a clear enhancement in the front-IQE of the rear side passivated cell compared to the aluminum reference. This gain is due to the enhancement in rear reflection for $\mathrm{SiN}_{\mathrm{x}}$ coatings compared to the full aluminum rear side. PC1D fits give $R_{\text {rear }}=72 \%$ for the aluminum reference versus $85 \%$ for the $\mathrm{SiN}_{\mathrm{x}}$ passivated solar cells. This improved optical confinement is reflected in the increased $\mathrm{J}_{\mathrm{sc}}$ of the PASHA cells.

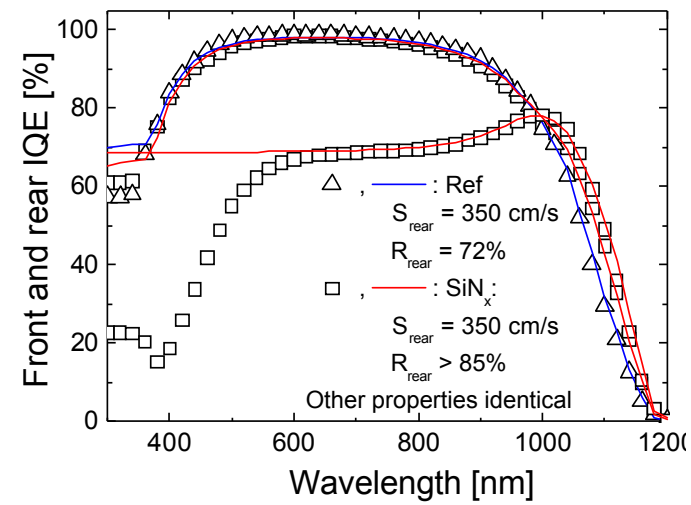

Figure 5: front and rear IQE of a rear side passivated (using passivating $\mathrm{SiN}_{\mathrm{x}}$ ) solar cell, and front IQE of a full aluminum rear solar cell.

\section{INDUSTRIALIZATION OF PASHA}

\section{From laboratory to an industrial cell line}

Processing of PASHA cells is similar to processing of standard, mc-Si solar cells with a full aluminum rear surface. The differences are highlighted red in the process flow in figure 6.

\begin{tabular}{|c|}
\hline Isotexture \\
\hline Emitter diffusion \\
\hline Rear emitter removal, smoothening \\
\hline P-glass removal, clean \\
\hline Front side IiN $_{x}$ \\
\hline Rear side passivating layer \\
\hline Ag front metallization \\
\hline Al and Ag rear metallization \\
\hline Co-firing \\
\hline Adjusted rear metallization pattern \\
\hline
\end{tabular}

Figure 6: process flow of the PASHA cells. The steps highlighted in red are additions or changes compared to the standard mc-Si processing with a full aluminium rear surface.

The first step that is different from the standard solar cell processing is the rear side emitter removal and smoothening. However, this process step is very similar to the wet chemical process for emitter isolation that is more and more used in industry. The difference lies in the fact that besides emitter removal, the rear surface also needs to be smoothened and cleaned for better passivation. The aim is to remove as little as possible from the rear side of the wafers to obtain a high throughput while still maintaining a good surface passivation. Preliminary results obtained our new single side etch are promising. We have obtained similar $V_{o c}$ and $J_{s c}$ on solar cells using batch or inline processing of the rear surface.

The second process step added to the standard cell processing is the application of a rear side passivating dielectric $\left(\mathrm{SiN}_{\mathrm{x}}\right)$ layer. We apply this layer using our remote MW PECVD system. Remote MW PECVD systems are already widely used in industry for the deposition of the front side ARC. By adjusting the parameters of the PECVD system we were able 
to make a very good -single- surface passivating layer (see figure 2). This will make the industrialization of the second step straightforward.

The final process step that needs to be industrialized, is the adjusted aluminum pattern on the rear side. A similar pattern is applied on the rear side to that on the front side for the first PASHA cells. This was an $\mathrm{H}$-pattern with 2 busbars, connected with thin fingers. The challenge here lies in optimizing both the rear surface passivation (less metallization) and the FF (more metallization). As the wafer size increases, the impact of the amount of metallization on the FF becomes more and more severe. This point will be addressed in more detail in the following paragraph.

\section{Metallization on larger sized solar cells}

The total recombination velocity $\left(\mathrm{S}_{\text {eff,total }}\right)$ on the rear side is determined by both the recombination velocity of the $\mathrm{SiN}_{\mathrm{x}}\left(\mathrm{S}_{\mathrm{eff}, \mathrm{SiN} x}\right)$ and the recombination velocity of the local BSF below the metallic (fired through) contacts ( $\left.S_{\text {eff,metal }}\right)$. The local BSF below the metal contacts is not be good as the BSF of a full Al covered solar cell, and gives a recombination velocity around $2000-3000 \mathrm{~cm} / \mathrm{s}$. If the percentage of metal coverage becomes larger, the total $S_{\text {eff,rear }}$ becomes dominated by $S_{\text {eff,metal, and both }} \mathrm{V}_{\mathrm{oc}}$ and $\mathrm{J}_{\mathrm{sc}}$ will drop. This effect is shown for $243 \mathrm{~cm}^{2}$ cells in figure 7 .

On the other hand, when the metal coverage becomes too small, the series resistance will increase (for instance increase in $\mathrm{R}_{\text {serie }}$ due to finer lines) and the FF will drop. Because of the larger generated current, and longer length of the fingers, the drop in FF is more explicit for $243 \mathrm{~cm}^{2}$ than for $156 \mathrm{~cm}^{2}$ wafers. By comparing different measuring methods of the solar cells (measuring only on the busbars or measuring on a chuck in a standard solar simulator) we found that the FF is mainly limited by the conductivity of the aluminum fingers.

The challenge for large PASHA cells is to minimize the metal coverage on the rear, while maintaining a good FF. Several approaches to tackle this problem are:

- Increasing the local BSF formation below the aluminum lines. This will improve the $\mathrm{V}_{\mathrm{oc}}$ and $\mathrm{J}_{\mathrm{sc}}$ for higher metallization coverage

- Increasing the conductivity of the aluminum lines to obtain higher FF

- Optimizing the metallization pattern on the rear side.

Research on all these topics is currently ongoing at ECN. A paper on the optimization of the metallization pattern using $2 \mathrm{D}$ simulations is presented at this conference by $\mathrm{E}$. Bende et al.

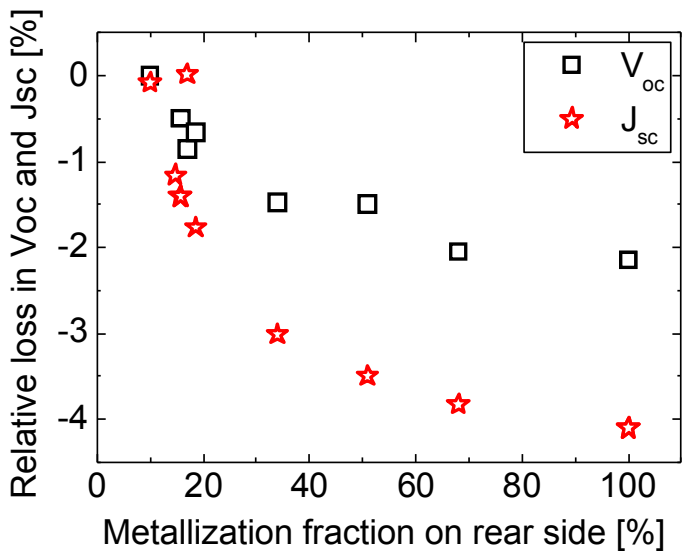

Figure 7: Effect of metallization on $\mathrm{V}_{\mathrm{oc}}$ and $\mathrm{J}_{\mathrm{sc}}$. The values are shown relative to the cell with the lowest amount of metallization: $10 \%$. All cells are made out of $243 \mathrm{~cm}^{2}, 180 \mu \mathrm{m}$ thin material.

\section{Processing thin and large solar cells}

The cell processing described in the previous paragraphs, using the best passivating $\operatorname{SiN}_{\mathrm{x}}$, was applied on $243 \mathrm{~cm}^{2}, 160 \mu \mathrm{m}$ thin wafers. The metallization pattern on the rear was not optimized yet on these large solar cells. Nevertheless, still efficiencies of over $16 \%$ were reached, with an average efficiency of $15.5 \%$. Maximum values obtained for $V_{o c}$ and $J_{s c}$ were $608 \mathrm{mV}$ and 34.3 $\mathrm{mA} / \mathrm{cm}^{2}$ compared to $605 \mathrm{mV}$ and $33.8 \mathrm{~mA} / \mathrm{cm}^{2}$ for the fully Al covered reference.

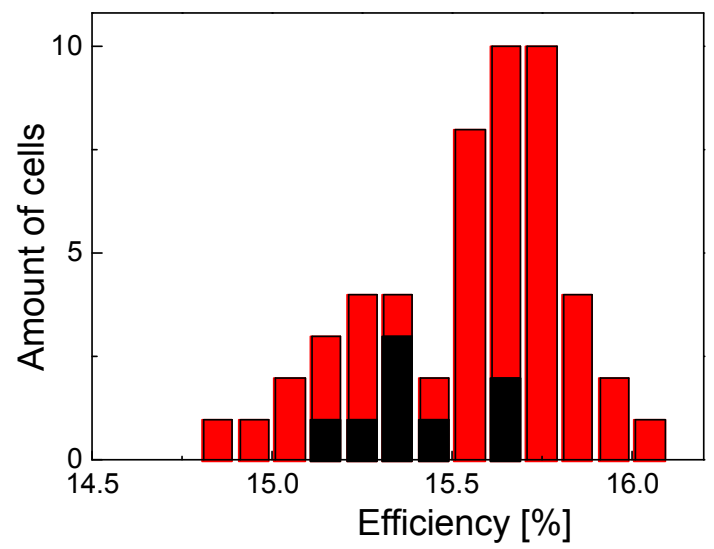

Figure 8: Red: the efficiencies of $60156 \times 156 \mathrm{~mm}^{2}$, $160 \mu \mathrm{m}$ thick rear side passivated solar cells. Black: 10 reference full Al cells (neighboring wafers)

A larger batch of these thin wafers was processed, to test the industrial applicability of the process flow. The results for 60 wafers are shown in figure 8 . Also the full AI BSF reference cells are shown (less wafers were processed for the reference). It is clear, that although the metallization pattern at the rear is not yet fully optimized with respect to $R_{\text {serie }}$ and passivation, the processing is relatively stable and gives an efficiency distribution that is $0.5 \%$ absolute higher than the reference, full aluminum covered process. The maximum efficiency reached is $16.1 \%$. On top of this, the bowing is reduced to zero for the bifacial cells, compared to $>2 \mathrm{~mm}$ for the reference cells. In the coming months, the processing on large 
wafers will be optimized and consecutively implemented into a full industrial process sequence up to module assembly.

\section{CONCLUSIONS}

In this paper we present rear side $\mathrm{SiN}_{x}$ passivated bifacial solar cell concept PASHA, and the steps that are undertaken for the industrialization of this cell concept. A highest efficiency of $16.4 \%$ was reached on PASHA cells made from $240 \mu \mathrm{m}$, $125 \times 125 \mathrm{~mm}^{2} \mathrm{mc}-\mathrm{Si}$ material, with $3 \%$ higher $\mathrm{J}_{\mathrm{sc}}$ and similar $V_{o c}$ compared to the full aluminum BSF reference cells. The gain in $\mathrm{J}_{\mathrm{sc}}$ is mainly due to the enhanced optical confinement from the rear $\mathrm{SiN}_{\mathrm{x}}$, while the $V_{o c}$ is governed by the rear surface recombination velocity $S_{\text {eff,rear. Lowest }} S_{\text {eff,rear }}$ of 350 $\mathrm{cm} / \mathrm{s}$ were reached which is a factor 3 better than the $S_{\text {eff,rear }}$ obtained in industry $(\sim 1000 \mathrm{~cm} / \mathrm{s})$ with full aluminum BSF. This means that passivation by $\mathrm{SiN}_{\mathrm{x}}$ should result in a large increase for both $\mathrm{V}_{\mathrm{oc}}$ and $\mathrm{J}_{\mathrm{sc}}$. For wafers thinner than $200 \mu \mathrm{m}$ the rear surface passivation will be even more important and therefore these increases will become even more significant. A large batch of $160 \mu \mathrm{m}$ thin, $156 \times 156$ $\mathrm{mm}^{2}$ wafers solar was successfully processed yielding an average efficiency of $15.5 \%$ and maximum efficiency of $16.1 \%, 0.5 \%$ absolute higher than the full $\mathrm{Al}$ reference.

\section{REFERENCES}

[1] L. Janssen et al., Progress in Photovoltaics: Res and Appl 15, 2007, 469-475

[2] I. G. Romijn et al., Proceedings $21^{\text {st }}$ EPVSEC, Dresden, September 2006, 717; Proceedings $22^{\text {nd }}$ EPVSEC, Milano, September 2007

[3] M. Hofmann et al., Proceedings $21^{\text {st }}$ EPVSEC, Dresden, September 2006

[4] M. Hofmann et al., Proceedings $22^{\text {nd }}$ EPVSEC, Milano, September 2007

[5] G. Agostinelli et al., Proceedings $21^{\text {st }}$ EPVSEC, Dresden, September 2006;

[6] P. Choulat et al., Proceedings $22^{\text {nd }}$ EPVSEC, Milano, September 2007

[7] C. J. J. Tool et al., Solar Energy Mat. and Solar Cells 90, 2006, 3165-3173

[8] C. J. J. Tool et al., Proc. 20th EPVSEC, Barcelona, June 2005

[9] I. Romijn et al., 15th Workshop on crystalline silicon solar cells \& modules: Materials and Processes, Vail, colorado, 2005, 82-85

[10]R. A. Sinton and A. Cuevas, Appl, Phys. Lett 96, 1996, 2510

[11]M. Greene, Solar Cells, operating principles, UNSW, Australia, 1982

[12]P.A. Basore, D.A. Clugston, PC-1D v5.5, University New South Wales 2000 